American Journal of Environmental Sciences 1 (4): 249-253, 2005

ISSN 1553-345X

(C) 2005 Science Publications

\title{
Noninvasive Environmental Monitoring of Mercury in Alaskan Reindeer
}

\author{
${ }^{1}$ Lawrence K. Duffy, ${ }^{1}$ Richard J. Hallock, ${ }^{2}$ Greg Finstad and ${ }^{3}$ R. Terry Bowyer \\ ${ }^{1}$ Department of Chemistry and Biochemistry, Box 756160, University of Alaska Fairbanks \\ Fairbanks, AK 99775-6160, United States \\ ${ }^{2}$ Reindeer Research Program, Plant, Animal and Soil Department, School of Natural Resources and \\ Agricultural Sciences, University of Alaska Fairbanks, Fairbanks, AK 99775-7140, United States \\ ${ }^{3}$ Department of Biological Sciences, Idaho State University, Pocatello, Idaho, 83209-8007 United States
}

\begin{abstract}
Reindeer, Rangifer tarandus, are terrestrial herbivores used by Alaskan Native herders for both subsistence food and commercial export. Reindeer are a renewable resource and as part of the food system are monitored for Mercury ( $\mathrm{Hg}$ ) levels in relation to the changing Arctic environment. In this study, both free-ranging reindeer from the Seward Peninsula, Alaska, and reindeer reared at the University of Alaska Fairbanks were analyzed for total mercury (THg) in their hair. Free-ranging reindeer of the Gray herd had mean hair THg levels of $75.4 \mathrm{ng} \mathrm{g}^{-1}(\mathrm{n}=15)$, whereas the Noyakuk herd had mean THg levels in hair of $40.3 \mathrm{ng} \mathrm{g}^{-1}(\mathrm{n}=12)$. The mean level in hair for THg in the university herd was $15.4 \mathrm{ng} \mathrm{g}^{-1}(\mathrm{n}=46)$. Methylmercury also was analyzed in selected samples from both herds; the mean for the Gray herd $\left(37.6 \mathrm{ng} \mathrm{g}^{-1}, \mathrm{n}=5\right)$ was higher than the mean for the Noyakuk herd (20.7 $\mathrm{ng}$ $\mathrm{g}^{-1}, \mathrm{n}=2$ ). Higher THg concentrations in the Gray and Noyakuk herds, when compared to the UAF herd, support the hypothesis that reindeer with higher lichen and willow levels in their diet have higher levels of THg.
\end{abstract}

Key words: Rangifer tarandus, reindeer, mercury, hair, Alaska, environmental monitoring

\section{INTRODUCTION}

Mercury $(\mathrm{Hg})$ is a naturally occurring element in both terrestrial and aquatic Alaskan ecosystems ${ }^{[1,2,3]}$. Small quantities of $\mathrm{Hg}$ are released in particulate form by normal weathering processes and are vaporized into the atmosphere from soils and occasional volcanic activity. Elemental mercury $\left(\mathrm{Hg}^{\circ}\right)$ and its inorganic form (HgII) are poorly absorbed by mammals but the organic methyl form $(\mathrm{MeHg})$ is readily absorbed ${ }^{[4]}$. $\mathrm{Hg}$ as $\mathrm{MeHg}$ is biomagnified up the food web, most likely as methylmercury cysteine in proteins ${ }^{[5]}$. Anthropogentic sources such as mining, coal-fired power plants and waste incinerators have led to an increase of bioavailable mercury in the Alaska environment. Many of these anthropogenic sources are outside of Alaska and the Arctic ${ }^{[2,6]}$.

Both $\mathrm{Hg}$ and $\mathrm{MeHg}$ are toxic, but $\mathrm{MeHg}$ has caused neurological and developmental disorders in humans ${ }^{[4,7,8]}$. The risk of fetal brain damage increases when the mercury concentration in maternal hair exceeds 10-20 $\mu \mathrm{g} \mathrm{g}^{-1}$. This threshold was based on studies of ingested mercury-contaminated grain, but long-term effects can be noticed at one-half that level, especially in complex neurological functions such as language. Elevated mercury concentrations have been reported in rural Alaskans who have a substantial amount of fish in their diet ${ }^{[9]}$. Although these levels are far from life threatening, they may have long-term effects on an individual's cognitive ability and cardiovascular system ${ }^{[10]}$. Only recently have ecological and human assessments been proposed in a comprehensive way for Alaska.

Reindeer (Rangifer tarandus) are associated with the tundra biome ${ }^{[11-14]}$. These large herbivores were introduced to Alaska around 1891 by Christian missionary Sheldon Jackson as a source of food to supplement the scarcity of caribou on the Seward Peninsula and eventually developed into a sustainable cash economy through the sale of meat and hides. At its peak in the 1930s, reindeer herding accounted for 500,000 reindeer in Alaska. Later, reindeer populations declined due to overgrazing, disease and an increase in caribou populations ${ }^{[15]}$. Currently, Alaskan Native herders manage about 25,000 reindeer divided into $>10$ herds on the Seward Peninsula.

Data on long-term trends for $\mathrm{Hg}$ in hair is rare for Alaskan reindeer ${ }^{[16,17]}$. Mercury analysis on hair samples is commonly used to assess accumulation of this toxic metal in wildlife ${ }^{[1,3,18-21]}$ as well as in evaluating human exposure ${ }^{[9,22]}$ to this heavy metal. There are advantages and disadvantages to using $\mathrm{THg}$ levels in hair as a biomarker of exposure; nevertheless, $\mathrm{THg}$ in hair has served as a useful survey tool to assess

Corresponding Author: Lawrence, K. Duffy, Department of Chemistry and Biochemistry, Box 756160, University of Alaska Fairbanks, Fairbanks, AK 99775-6160, United States, Tel.: +1 907474 7525; Fax: +1 9074745101 
the changes in the occurrence of environmental exposure to mercury ${ }^{[18-21]}$. The aim of this study was to demonstrate that noninvasive environmental monitoring of mercury can provide baseline information on reindeer to herders and scientists. If in future years, reindeer diets change, then changes in exposure to $\mathrm{Hg}$ could be detected.

\section{METHODS}

We collected full-length samples of guard hairs from the back of reindeer on the Seward Peninsula, Alaska, (Fig. 1) and those housed at the University of Alaska Fairbanks. Two herds from the Seward Peninsula were sampled. The range of the Gray herd was coastal while the Noyakuk herd range was inland and at a slightly higher elevation. The general latitude and longitude for the herds are $65^{\circ} \mathrm{N}$ and $165^{\circ} \mathrm{Wwith}$ a range of $5,000 \mathrm{~km}^{2}$ per herd.

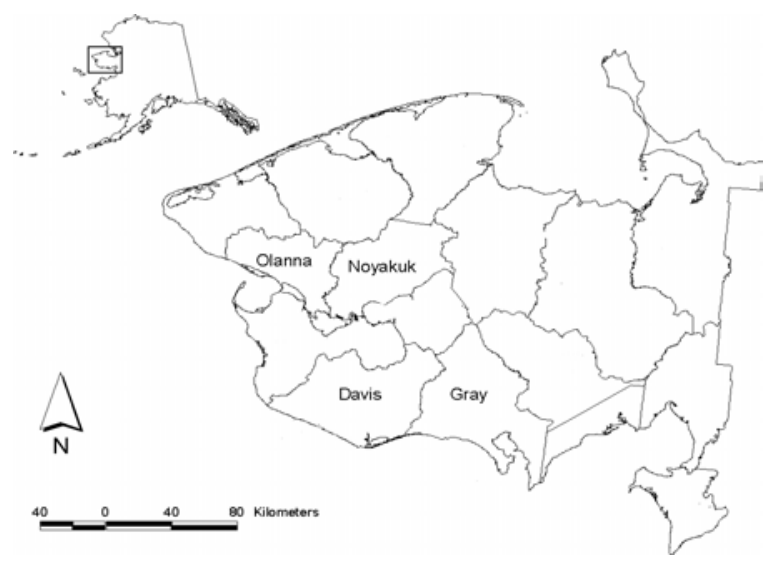

Fig. 1: Location of gray and noyakuk reindeer herd ranges on the Seward Peninsula, Alaska

Hair samples were washed with trace metals free detergent prior to digestion. The washes were performed using 5 consecutive $10 \mathrm{~mL}$ rinses of detergent. For the first two rinses, the samples were shaken every 10 minutes for 1 hour. The final three rinses were performed by shaking the sample for 1 minute in $10 \mathrm{~mL}$ of detergent followed by the removal of the detergent with a pipette. After the washing was complete, the hair was dried overnight in an oven at $\sim 65^{\circ} \mathrm{C}$.

$\mathrm{THg}$ concentrations in hair samples were measured at Frontier Geosciences (Seattle, WA) using the cold vapor atomic fluorescence spectrometry (CVAFS) method $^{[17]}$. Results were reported on a wet weight (w/wt) basis as ng/g (ppb). All analyses were performed with a thorough quality-control program using certified reference DOLT-3.

Sample digestion: For total mercury in tissue, approximately $0.25 \mathrm{~g}$ of each reindeer hair sample was digested with $10 \mathrm{~mL}$ of hot refluxing $70 \% \mathrm{HNO}_{3}: 30 \%$ $\mathrm{H}_{2} \mathrm{SO}_{4}$ for approximately 2 hours. The digests were then diluted to a final volume of $40 \mathrm{~mL}$ with a solution of $10 \%(\mathrm{v} / \mathrm{v}) 0.2 \mathrm{~N} \mathrm{BrCl}$.

THg analysis: Digested reindeer hair was analyzed for total $\mathrm{Hg}$ in accordance with the standard operating procedures described in the Frontier Geosciences Quality Assurance manual. Aliquots of each digest were reduced in pre-purged double-distilled water to $\mathrm{Hg}^{0}$ with $\mathrm{SnCl}_{2}$ and then the $\mathrm{Hg}^{0}$, purged onto gold traps as a preconcentration step. The $\mathrm{Hg}$ contained on the gold traps was then analyzed by thermal desorption into a cold vapor atomic fluorescence detector (CVAFS) with the dual amalgamation technique.

Quality control: Daily analytical runs were begun with an 8 point standard curve, spanning the entire analytical range of interest, with additional standards analyzed every 10 samples. The daily standard curves were calculated with the blank-corrected initial standards and a linear regresson forced through zero. For each analytical set, one matrix duplicate, two matrix spikes and at least three method blanks were co-processed and analyzed in exactly the same manner as ordinary samples. The mean of blanks were $0.16 \pm .01 \mathrm{ng} \mathrm{g}^{-1}$. The recovery of the DOLT-3 reference averaged $98.9 \%$ and the Spike recovery averaged $101.1 \%$. Variation of duplicate samples was $6.1 \%$.

MeHg analysis: Methyl mercury in hair was prepared by $\mathrm{KOH} /$ methanol digestion and analyzed by aqueous phase ethylation, isothermal GC separation and CVAFS detection $^{[17]}$. The samples for methyl mercury were analyzed at a dilution of $40 \mathrm{x}$ to reduce interferences form the protein in the hair samples.

MeHg quality control: The mean of blanks was $0.6 \mathrm{ng}$ $\mathrm{g}^{-1}$. The recovery of the DOLT-3 reference was $104.4 \%$ and DORM-2 was $102.3 \%$. The analysis of variation of duplicates was $8.9 \%$ and the matrix spike recovery was $85.7 \%$.

\section{RESULTS}

Hair from all ages of UAF reared reindeer showed a moderate range for $\mathrm{THg}$ levels (Table 1). The mean and standard deviation for the $\mathrm{THg}$ concentration was $15.4 \mathrm{ng} \mathrm{g}^{-1} \pm 4.1(\mathrm{n}=46)$. Male reindeer had a mean $\mathrm{THg}$ concentration of $14.7 \mathrm{ng} \mathrm{g}^{-1} \pm 4.8(\mathrm{n}=15)$ and female reindeer had a mean $\mathrm{THg}$ concentration of $15.9 \mathrm{ng} \mathrm{g}^{-1}$ $\pm 4.0 \quad(n=31)$. The correlation between age of UAF reindeer and $\mathrm{THg}$ was weak. This analysis did not support the hypothesis that increased age will lead to increased hair THg levels. Both the male and female subgroups also showed no correlation between age and $\mathrm{THg}$, as is evident by a $\mathrm{R}^{2}$ value of 0.148 for males and a value of 0.0099 for females. 
Am. J. Environ. Sci., 1 (4): 249-253, 2005

Table 1: Mercury in the hair of Alaskan reindeer from the Seward Peninsula (ng/g (w/w)

\begin{tabular}{lcccc}
\hline Herd & $\mathrm{n}$ & mean $\left(\mathrm{ng} \mathrm{g}^{-1}\right)$ & S.D. & Range \\
\hline Total Mercury & & & & $47.5-103$ \\
Gray & 15 & 73.1 & 17.0 & $24.3-49.8$ \\
Noyakuk & 12 & 38.4 & 7.5 & $8.5-27$ \\
UAF (total) & 46 & 15.4 & 4.1 & $8.5-24$ \\
UAF male & 15 & 14.7 & 4.8 & $9.5-27$ \\
UAF female & 31 & 15.9 & 4.0 & $24.3-56.6$ \\
Methyl Mercury & & & 13.9 & $18.6-27.7$ \\
Gray & 5 & 37.6 & -- & \\
Noyakuk & 2 & 20.7 &
\end{tabular}

Hair from the two free-ranging herds differed in mean levels of $\mathrm{THg}$ (Table 1) with the Gray herd showing a mean of $73.1 \mathrm{ng} \mathrm{g}^{-1}$ and the Noyakuk herd with a lower mean (38.4 $\left.\mathrm{ng} \mathrm{g}^{-1}\right)$. MeHg, which was determined in selected samples, followed the same pattern with the Gray herd having a higher mean level. The mean MeHg level for the Gray herd was $37.6 \mathrm{ng}$ $\mathrm{g}^{-1}(\mathrm{n}=5)$ and the mean for the Noyakuk herd was 20.7 $n \mathrm{~g} \mathrm{~g}^{-1}(\mathrm{n}=2)$. For the Gray herd, the ratio of MeHg:THg was $51 \%$. The THg levels for both free ranging herds were higher than the UAF herd which had a mean level of $15.4 \mathrm{ng} \mathrm{g}^{-1}$.

\section{DISCUSSION}

Environmental monitoring studies on Arctic terrestrial mammals have increased over the last 20 years ${ }^{[2,6,11,14,23,24]}$. Although THg levels tend to be lower in terrestrial mammals, because of fewer trophic steps in terrestrial food webs, terrestrial systems are valuable for monitoring changes in mercury distribution related to both local disturbance, such as industrial activity, or more general indirect effects such as global climate change, or global transport of contaminants. Noninvasive monitoring methods for mercury can be used to detect changes in exposure in animal populations ${ }^{[25]}$ and the reindeer has the characteristics for a good sentinel species for terrestrial environments in many areas of Alaska ${ }^{[16,26]}$.

Lichens (Cetraria spp.) has been used as a biomonitor ${ }^{[27,28]}$ and play an important role in the diet of reindeer and caribou during winter and early spring $^{[24,29]}$. Lichens are long-lived and accumulate atmospheric contaminants such as mercury in a nonselective manner ${ }^{[12,30]}$. Caribou that feed substantially on lichen would accumulate higher levels of mercury. The difference (Table 2) we observed previously between caribou at UAF and those at Teskekpuk could be explained by the higher component of dietary lichens in free-ranging caribou. The relationship of $\mathrm{Hg}$ level with amount of lichens in the diet was suggested earlier. Froslie et al. ${ }^{[30]}$ reported reindeer to have higher mercury burdens than moose (Alces alces), roe deer (Capreolus capreolus) and red deer (Cervus elaphus) in Norway. In that study, reindeer foraged mainly on lichens, whereas moose, roe deer and red deer foraged on shrubs, grasses, or herbaceous plants. Aastrup et al. ${ }^{[1]}$ also suggested that winter forage rich in lichens could explain variations in $\mathrm{Hg}$ levels. Lichen levels are similar in the diets of the Gray and Noyakuk herds at about 40 to $50 \%{ }^{[31]}$; consequently, lichens do not explain all of our observed differences in means for free-ranging reindeer.

Table 2: Mean total mercury concentrations (ng/g) in different reindeer and caribou, Alaska, USA

\begin{tabular}{llrc}
\hline \multicolumn{1}{l}{} & Herbivore & $\mathrm{n}$ & $\bar{x}$ (Range) \\
\hline Caribou $^{\mathrm{a}}$ & & & \\
& UAF-LARS (1998) & 2 & $3.6(2.5-4.6)$ \\
& Teskekpuk (1997) & 11 & $47.1(7.5-66.2)$ \\
& Teskekpuk (1998) & 11 & $62.7(44.2-85.1)$ \\
Reindeer & & & \\
& UAF-LARS (1998) & 4 & $4.1(2.4-6.1)$ \\
& Fishmeal (2003) & 10 & $30.8(1.5-43.3)$ \\
& UAF-RPP (2005) & 46 & $15.4(8.5-27)$ \\
& Gray (2005) & 15 & $73.1(47.5-1003)$ \\
& Noyakuk (2005) & 12 & $38.4(24.3-49.8)$ \\
\hline
\end{tabular}

${ }^{\mathrm{a}}$ Duffy et al. $\left[{ }^{16}\right.$

${ }^{\mathrm{b}}$ Duffy et al. ${ }^{[17]}$

In Alaska, hair analysis of captive caribou $(\mathrm{n}=2,3.6$ $\mathrm{ng} \mathrm{g}^{-1}$ ) and the free-ranging caribou indicated that freeranging north central caribou were more exposed to $\mathrm{Hg}$ $\left(\mathrm{n}=11,47.1 \mathrm{ng} \mathrm{g}^{-1}, 1997\right)^{[16]}$. This survey (Table 2) indicates that free-ranging western Alaska reindeer and caribou have similar THg in their hair (73.1 and $38.4 \mathrm{ng}$ $\mathrm{g}^{-1}$ versus 62.7 and $\left.47.1 \mathrm{ng} \mathrm{g}^{-1}\right)$. Duffy et al. ${ }^{[16]}$ demonstrated that the free-ranging caribou from the Teskekpuk Lake region of north-central Alaska showed similar variation in mean levels $\left(1997,47.1 \mathrm{ng} \mathrm{g}^{-1}\right.$ $\left.(\mathrm{n}=11) ; 1998,62.7 \mathrm{ng} \mathrm{g}^{-1}, \mathrm{n}=11\right)$. Aastrup et al. ${ }^{[11]} \mathrm{using}$ tissue samples showed similar variation with $\mathrm{Hg}$ levels ranging from $3 \mathrm{ng} \mathrm{g}^{-1}$ wet weight (ww) to $43 \mathrm{ng} \mathrm{g}^{-1}$ (ww) in Greenland reindeer and caribou.

Free-ranging reindeer and caribou eat a mixture of vegetation including lichens. Reindeer that were fed substantially on lichen would accumulate higher levels of mercury. The THg levels of caribou from Teskekpuk region of Alaska had been hypothesized to be from the higher natural lichen component in their diet than the UAF herd ${ }^{[16]}$. Aastrup et al. ${ }^{[11]}$ also suggested that the availability of lichens as winter forage was the key factor determining the level of elements. Nonetheless, the Gray herd with a THg mean level similar to the 
Teskekpuk caribou and the Noyakuk with a lower THg mean suggests more detail is needed in this hypothesis.

Recent studies ${ }^{[31]}$ have shown that these herds of reindeer are grazed on defined ranges across the Seward Peninsula, Alaska. Variation in species composition, particularly the proportion of shrubs to graminoids exists across these ranges. Data from diet composition analysis measured in reindeer indicated that the proportion of willow species to graminoids and lichen in the spring and early summer diet was higher in herds on shrub-dominated ranges $(42.4 \%+5.4$ vs. $20 \%+$ 2.7). Aastrup et al. ${ }^{[11]}$ also reported the presence of dietary spatial patterns in Greenland reindeer and caribou.

The THg variation we observed in these two reindeer herds on different ranges may be related to differences in the proportion of willows in the diet. For example, tannins in willows may inhibit the absorption of $\mathrm{Hg}$ or may have an effect on methylation or dimethylation in the reindeer rumen. The discussion regarding foraging and metal bioaccumulation in a changing Arctic enviroment needs to include details on changes in plant community composition as well as species-specific variations in $\operatorname{diets}^{[32]}$. While comparisons between ranges must be performed with caution and knowledge of the winter diet, we conclude that reindeer perform well as a bioindicator or sentinel species in Alaska.

\section{ACKNOWLEDGEMENTS}

This research was funded in part a grant from the UA Natural Resources fund grant 182113. Lawrence K. Duffy was supported, in part, by NINDS/NIMH/NCRR grant U54NS41069. We are grateful for the assistance of Robert Aikman and Susanne Worker, as well as Amy Dahl.

\section{REFERENCES}

1. Ben-David, M., L.K. Duffy, G.M. Blundell, R.T. Bowyer, 2001. Natural exposure to mercury in coastal river otters: age, diet and survival. Environ. Toxicol. Chem., 20: 1986-92.

2. Braune, B., D. Muir, B. Demarch, M. Gamberg, K. Poole, R. Currie et al., 1999. Spatial and temporal trends of contaminants in Canadian Arctic freshwater and terrestrial ecosystems: a review. Sci. Total Environ., 230: 145-208.

3. Beckman, K.B., L.K. Duffy, X. Zhang, K.W. Pitcher, 2002. Mercury concentrations in the fur of Steller sea lions and northern fur seals form Alaska. Mar. Pollut. Bull., 44: 1130-5.

4. Clarkson, T.W. and N. Ballatori, 2002. Molecular biomarkers for mercury. In: Wilson SH, Suk WA, editors. Biomarkers of environmentally associated disease. Boca Raton: Lewis Pubs., pp: 225-235.
5. Harris, H.H., I.J. Pickering and G.N. George, 2003. The chemical form of mercury in fish. Science, 301: 1203.

6. AMAP, 2002. Arctic pollution. Tromso, Norway: Arctic Council Publication.

7. Davidson, P.W., G.J. Myers and B. Weiss, 2004. Mercury exposure and child development outcomes. Pediatrics, 113(suppl): 1023-1029.

8. Goyer, R.A. and T.W. Clarkson, 2001. Toxic Effect of Metals. In: Klaassen CD, Ed. Casarett and Doull's Toxicology. New York: McGraw-Hill, pp: 811-867.

9. Rothschild, R.F.N. and L.K. Duffy, 2002. Methylmercury in the hair of subsistence food users in a rural Alaskan village. Alaskan Med., 44: 2-7.

10. Guallar, E., M.I. Sanz-Gallardo, P. Van't Veer, P. Bode, A. Aro, J. Gomez-Aracena, J. D. Kark, R.A. Riemersma, J.K. Martin-Moreno and F.J. Kok, 2002. Mercury, fish oils and the risk of myocardial infarction. New Engl. J. Med., 347: 1747-1754.

11. Aastrup, R.F., R. Dietz and G. Asmund, 2000. Lead, zinc, cadmium, mercury, selenium and copper in Greenland caribou and reindeer (Rangifer tarandus). Sci. Tot. Environ., 245: 148-159.

12. Crete, M.L., L. Libefore and P. Walsh, 1992. Cadmium, lead, mercury and cesium in fructicose lichens of northern Quebec. Sci. Total Environ., 121: 217-30.

13. Elkin, B.T. and R.W. Bethke, 1995. Environmental contaminants in caribou in the Northwest Territories, Canada. Sci. Total Environ., 161: 307-21.

14. Gamberg, M., B. Braune, E. Davey, B. Elkin, P.F. Hoekstra et al., 2005. Spatial and temporal trends of contaminants in terrestrial biota from the Canadian Arctic. Sci. Total Environ., 351: 148-164.

15. Ewing, S. The Great Alaska Native Factbook, Alaska Northwest Books, Anchorage, pp: 223.

16. Duffy, L.K., C. Kaiser, C. Ackley and K.S. Richter, 2001. Mercury in the hair of large Alaskan herbivores: routes of exposure. Alces, 37: 293-301.

17. Duffy L.K., R.S. Duffy, G. Finstad, C. Gerland, 2005. A note on mercury levels in the hair of Alaskan reindeer. Sci. Total Environ., 339: 273-276.

18. Harkins, D.K. and A.S. Susten, 2003. Hair analysis: Exploring the state of science. Environ. Health Perspect., 111: 576-8.

19. Madsen, A.B. and C.F. Mason, 1987. Cadmium, lead and mercury in hair from Danish otters Lutra lutra. Nat. Jutl., 22: 81-4.

20. Pereira, R., R. Ribeiro and F. Goncalves, 2004. Scalp hair analysis as a tool in assessing human exposure to heavy metals $\mathrm{S}$ Domingos Mine, Portugal. Sci. Total Environ., 327: 81-2.

21. Bozsai, G., 1992. Quality control and assurance in hair analysis. Microchem. J., 46: 159-66. 
22. Cerneichiari, E., R. Brewer and J.G. Meyers, 1995. Monitoring methylmercury during pregnancy: Maternal hair predicts fetal brain exposure. Neurotoxicology, 16: 705-10.

23. Larter, N.C. and J.A. Nagy, 2000. A comparison of heavy metal levels in the kidneys of high arctic and mainland caribou populations in the Northwest Territories of Canada. Sci. Total Environ., 246: 109-19.

24. Erickson, O., A. Frank, M. Nordkuist and L.R. Peterson, 1990. Heavy metals in reindeer and their forage plants. Rangifer, Sp. Iss., 3: 315-31.

25. Stevens, R.T., T.L. Ashwood and J.M. Sleeman, 1997. Mercury in hair of muskrats and mink from the US Department of Energy Oak Ridge reservation. Bull. Environ. Contam. Toxicol., 58: 720-5.

26. Beeby, A., 2001. What do sentinels stand for. Environ. Pollut., 112: 285-298.

27. Thomas, D.J., B. Tracey and R.J. Norsstrom, 1992. Arctic terrestrial ecosystem contamination. Sci. Total Environ., 122: 135-64.
28. Riget, F., G. Asmund and P. Aastrup, 2000. The use of a lichen (Cetraria nivalis) and a moss (Rhacomitrium lanuginosum) as monitors for atmospheric deposition in Greenland. Sci. Total Environ., 245: 137-148.

29. Barten, N.L., R.T. Bowyer and K.J. Jenkins, 2001. Habitat use by female caribou: tradeoffs associated with parturition. J. Wildli. Manage., 65: 77-92.

30. Froslie, A., G. Nordheim, P.J. Ramback and E. Stiennes, 1984. Levels of trace elements in the liver from Norwegian moose, reindeer and red deer in relation to atmospheric deposition. Acta Vet. Scand., 25: 333-45.

31. Finstad, G. and K. Kielland, 2005. Climate change, environmental variation and reindeer productivity on the Seward Peninsula, Alaska. Arctic Sci. Conf., 56: 17-18.

32. Burger, J., M. Gochfeld, D. Kosson, C.W. Powers, B. Friedlander, J. Eichelberger, D. Barnes and L.K. Duffy et al., 2005. Science, policy and stakeholders: Developing a consensus science plan for Amchitka Island, Aleutians, Alaska. Environ. Manage., 35: 557-568. 